\title{
United States - Continued Dumping and Subsidy Offset Act of 2000 (WT/DS217/AB/R: DSR 2003:I,375)
}

\author{
HENRIK HORN* \\ Institute for International Economic Studies, Stockholm University \\ PETROS C. MAVROIDIS* \\ Columbia Law School, New York and University of Neuchâtel, Switzerland
}

\section{Introduction}

On January 16, 2003, the WTO Appellate Body (AB) issued its report on the appeal by the United States (US) of the Panel decision in United States - Continued Dumping and Subsidy Offset Act of 2000. ${ }^{1}$ The report concerns the consistency of the United States Continued Dumping and Subsidy Offset Act of 2000 (the "CDSOA," or the so-called Byrd Amendment) with several WTO provisions. This legislation requests the federal state to distribute proceeds from antidumping and countervailing duties to all US economic operators that have supported a request previously submitted to the ratione materiae competent US authority to investigate alleged dumping or subsidization. The appeal was directed against the Panel's finding that the Byrd legislation was inconsistent with the US obligations under the WTO Antidumping Agreement (AD), and the Agreement on Subsidies and Countervailing Measures (SCM). A total of 11 complainants (Australia, Brazil, Canada, Chile, the European Community, India, Indonesia, Japan, Korea, Mexico, and Thailand), and five additional third parties (Argentina,

* We thank Wilfred J. Ethier, Mark Koulen, Jasper-Martijn Wauters, and participants at the ALI conference organized in Geneva on April 12, 2005 for very helpful discussions.

${ }^{1}$ The AB report is WTO Doc. WT/DS217/AB/R and 234/AB/R. 
Costa Rica, Hong Kong (China), Israel, and Norway), evidence the interest among WTO Members in the issues at stake in the dispute.

The subject matter of the dispute was not the application of the Byrd legislation in a particular instance, but the legislation as such, irrespective of any application. The $\mathrm{AB}$ dealt with two substantive issues:

1. To what extent does the Byrd Amendment constitute a specific action against dumping, impermissible under Arts. 18.1 AD and 32.1 SCM?

2. To what extent does the United States, by transferring duty payments made by exporters to the market to domestic firms, comply with the obligations under Arts. 5.4 AD and 11.4 SCM?

The $\mathrm{AB}$, partially accepting the Panel's findings under Art. 18.1 AD, condemned the Byrd Amendment for being an offset payment that is neither a definitive antidumping duty, nor a provisional measure or a price undertaking. Since according to the $A B$, only these three forms of duties are permissible as specific action against dumping under the WTO AD Agreement, and since the Byrd Amendment is a measure to this effect, the $\mathrm{AB}$ concluded that the legislation violates US obligations under Art. 18.1 AD. Applying an identical rationale, the $\mathrm{AB}$ found that the Byrd Amendment also contravenes the SCM since, when used against subsidies, it counteracts subsidization in a different manner than what is permitted under the SCM. But the $\mathrm{AB}$ reversed the Panel's findings that the contested legislation violates Arts. 5.4 AD and 11.4 SCM by rendering the prescribed test of the support for an antidumping application meaningless. Neither did the $\mathrm{AB}$ accept the argument that the United States had acted in bad faith by enacting legislation that (in the Panel's view) is biased in favor of artificially supporting petitions to investigate. Having found that the United States was partially acting inconsistently with their obligations, the $\mathrm{AB}$ recommended that the United States bring its measures into compliance with its obligations.

In Sections 2 and 3 we summarize and discuss the adjudicating bodies', and in particular the AB's, analysis of the two main issues mentioned above. ${ }^{2}$ Section 4 examines possible alternative legal bases

${ }^{2}$ We concentrate on the substantive issues raised before the $\mathrm{AB}$. The $\mathrm{AB}$ also dealt with some procedural issues, most of which concerned the question whether some claims were properly before it or not (plus, an issue regarding submission of new evidence). 
for attacking the Byrd legislation. Section 5 briefly summarizes our main findings.

\section{Does the Byrd Amendment violate Arts. 18.1 AD and 32.1 SCM?}

Article 18.1 AD reads:

No specific action against dumping of exports from another Member can be taken except in accordance with the provisions of GATT 1994, as interpreted by this Agreement.

To this sentence a footnote is added:

This is not intended to preclude action under other relevant provisions of the GATT 1994, as appropriate.

Article 32.1 SCM contains an equivalent provision in the context of subsidies.

The adjudicating bodies address three requirements in Art. 18.1 AD: whether the Byrd Amendment is a "specific" action (see Section 2.1), whether it acts "against" dumping (Section 2.2), and if it is a specific action against dumping, whether it is nevertheless lawful, being "in accordance with the provisions of GATT 1994" (Section 2.3).

\subsection{Adjudicating bodies' interpretation of "specific"}

The $\mathrm{AB}$ summarizes the Panel's reasoning as follows ( $\$ \S 227-228$ of the $A B$ report):

Having decided that our ruling in US - 1916 Act was not dispositive of the issues in the present case, the Panel developed the following standard to determine whether a measure is a specific action against dumping or a subsidy: a measure will constitute specific action against dumping or a subsidy if: (1) it acts "specifically" in response to dumping or a subsidy, in the sense that the measure may be taken only in situations presenting the constituent elements of dumping or a subsidy; and (2) it acts "against" dumping or a subsidy, in the sense that the measure has an adverse bearing on the practice of dumping or on the practice of subsidization. (italics in the original, footnote omitted)

Applying this standard to the CDSOA, the Panel, as a preliminary matter, determined that the CDSOA is a "specific action related to" dumping or a subsidy. According to the Panel, the CDSOA meets the first condition of the standard because CDSOA payments may be made 
only in situations where the constituent elements of dumping (or of a subsidy) are present. The Panel also pointed out that CDSOA offset payments follow automatically from the collection of anti-dumping (or countervailing) duties, which in turn may be collected only following the imposition of anti-dumping (or countervailing duty) orders, which in turn may be imposed only following a determination of dumping (or subsidization). The Panel thus determined that the CDSOA is a specific action related to dumping (or subsidization) because there is a "clear, direct and unavoidable connection" between the determination of dumping (or subsidization) and CDSOA offset payments.

\section{The $\mathrm{AB}$ concurs with the Panel's finding:}

In our view, the Panel was correct in finding that the CDSOA is a specific action related to dumping or a subsidy within the meaning of Article 18.1 of the Anti-Dumping Agreement and Article 32.1 of the SCM Agreement. It is clear from the text of the CDSOA, in particular from Section 754(a) of the Tariff Act, that the CDSOA offset payments are inextricably linked to, and strongly correlated with, a determination of dumping, as defined in Article VI:1 of the GATT 1994 and in the Anti-Dumping Agreement, or a determination of a subsidy, as defined in the SCM Agreement. The language of the CDSOA is unequivocal. First, CDSOA offset payments can be made only if anti-dumping duties or countervailing duties have been collected. Second, such duties can be collected only pursuant to an anti-dumping duty order or countervailing duty order. Third, an anti-dumping duty order can be imposed only following a determination of dumping, as defined in Article VI:1 of the GATT 1994 and in the Anti-Dumping Agreement. Fourth, a countervailing duty order can be imposed only following a determination that exports have been subsidized, according to the definition of a subsidy in the SCM Agreement. In the light of the above elements, we agree with the Panel that "there is a clear, direct and unavoidable connection between the determination of dumping and CDSOA offset payments", and we believe the same to be true for subsidization. In other words, it seems to us unassailable that CDSOA offset payments can be made only following a determination that the constituent elements of dumping or subsidization are present. Therefore, consistent with the test established in US 1916 Act, we find that the CDSOA is "specific action" related to dumping or a subsidy within the meaning of Article 18.1 of the Anti-Dumping Agreement and of Article 32.1 of the SCM Agreement.

(§242, italics in the original, footnote omitted) 


\subsection{Adjudicating bodies' interpretation of "against"}

The second issue to be resolved is whether the Byrd Amendment is not only "related" to dumping, but acts "against" dumping. The AB distils the view of the Panel as follows:

... the Panel affirmed that Article 18.1 of the Anti-Dumping Agreement (and Article 32.1 of the SCM Agreement) concerns measures that act against dumping as a practice (or subsidization as a practice), and do not require that the measure at issue must act against the imported dumped (or subsidized) product, or entities connected to, or responsible for, the dumped (or subsidized) product, such as the importer, exporter, or foreign producer. The Panel added that the term "against" in Article 18.1 of the Anti-Dumping Agreement and Article 32.1 of the SCM Agreement encompasses measures having a direct, as well as indirect, adverse bearing on the practice of dumping (or subsidization).

Two considerations led the Panel to find that the CDSOA operates "against" dumping (or a subsidy), in the sense that it has an adverse bearing on dumping (or a subsidy). First, according to the Panel, the CDSOA acts against dumping (or a subsidy) by conferring on affected domestic producers, which incur qualifying expenses, an offset payment subsidy that would allow them to establish a competitive advantage over dumped (or subsidized) imports. Second, the Panel was of the view that the CDSOA has an adverse bearing on dumping (or a subsidy) because it provides a financial incentive for domestic producers to file anti-dumping (or countervail) applications, or at least to support such applications, in order to establish their eligibility for offset payments.

(\$229-230, italics in the original, underlining added, footnote omitted)

Concerning the consequence of the legislation that the Panel emphasizes - the direct effect on competitive conditions - the $\mathrm{AB}$ states the following:

We note that the United States challenges what it views as the Panel's incorporation of a "conditions of competition test" in Article 18.1 of the Anti-Dumping Agreement and in Article 32.1 of the SCM Agreement. In our view, in order to determine whether the CDSOA is "against" dumping or subsidization, it was not necessary, nor relevant, for the Panel to examine the conditions of competition under which domestic products and dumped/subsidized imports compete, and to assess the impact of the measure on the competitive relationship between them. An analysis of the term 'against', in our view, is more appropriately centred on the design and structure of the measure; such an analysis does not 
mandate an economic assessment of the implications of the measure on the conditions of competition under which domestic product and dumped/subsidized imports compete.

( $\$ 257$ of the report, op. cit., italics in the original, underlining added, footnote omitted)

We are not entirely certain whether this is a dismissal of the US' argument that the Panel is effectively undertaking a "conditions of competition test," or whether it is to say that the Panel overdid it, by making such a test. The conclusion is in any event the same: no such test is needed.

The AB firmly rejects the Panel's second argument for why the Byrd Amendment violates Arts. 18.1 AD and 32.1 SCM - that it provides the domestic industry with a financial incentive to submit antidumping petitions. In the AB's view, an incitation to act upon one's right is as such not a violation:

... the finding of the Panel that the CDSOA is a measure against dumping or a subsidy is also based on the view that the CDSOA provides a financial incentive for domestic producers to file or support applications for the initiation of anti-dumping and countervailing duty investigations, and that such an incentive will likely result in a greater number of applications, investigations and orders. We agree with the United States that this consideration is not a proper basis for a finding that the CDSOA is "against" dumping or a subsidy; a measure cannot be against dumping or a subsidy simply because it facilitates or induces the exercise of rights that are WTO-consistent. The Panel's reasoning would give Article 18.1 of the Anti-Dumping Agreement and Article 32.1 of the SCM Agreement a scope of application that is overly broad. For example, the Panel's reasoning would imply that a legal aid program destined to support domestic small-size producers in anti-dumping or countervailing duty investigations should be considered a measure against dumping or a subsidy within the meaning of Article 18.1 of the Anti-Dumping Agreement and of Article 32.1 of the SCM Agreement, because it could be argued that such legal aid is a financial incentive likely to result in a greater number or applications, investigations and orders.

(§258, italics in original, underlining added, footnote omitted)

So why, then, does the Byrd Amendment violate Arts. 18.1 AD and 32.1 SCM according to the AB? The central passage in the report reads:

Recalling the other two elements of the definition of "against" from the New Shorter Oxford Dictionary relied upon by the United States, 
namely "of motion or action in opposition" and "in hostility or active opposition to", to determine whether a measure is "against" dumping or a subsidy, we believe it is necessary to assess whether the design and structure of a measure is such that the measure is "opposed to", has an adverse bearing on, or, more specifically, has the effect of dissuading the practice of dumping or the practice of subsidization, or creates an incentive to terminate such practices. In our view, the CDSOA has exactly those effects because of its design and structure.

The CDSOA effects a transfer of financial resources from the producers/ exporters of dumped or subsidized goods to their domestic competitors ... there is no statutory or regulatory requirement as to how a CDSOA offset payment to an affected domestic producer is to be spent, thus indicating that the recipients of CDSOA offset payments are entitled to use this money to bolster their competitive position vis-à-vis their competitors, including the foreign competitors subject to anti-dumping or countervailing duties.

All these elements lead us to conclude that the CDSOA has an adverse bearing on the foreign producers/exporters in that the imports into the United States of the dumped or subsidized products (besides being subject to anti-dumping or countervailing duties) result in the financing of United States competitors-producers of like products-through the transfer to the latter of the duties collected on those exports. Thus, foreign producers/exporters have an incentive not to engage in the practice of exporting dumped or subsidized products or to terminate such practices. Because the CDSOA has an adverse bearing on, and, more specifically, is designed and structured so that it dissuades the practice of dumping or the practice of subsidization, and because it creates an incentive to terminate such practices, the CDSOA is undoubtedly an action "against" dumping or a subsidy, within the meaning of Article 18.1 of the AntiDumping Agreement and of Article 32.1 of the SCM Agreement."

( $\S 254-256$, italics in the original, underlining added, footnotes omitted)

\subsection{The AB's interpretation of whether the legislation is "in accordance with the provisions of GATT 1994"}

Having found that the Byrd Amendment is a specific action against dumping, the remaining question the $\mathrm{AB}$ addresses is whether it is "in accordance with the provisions of GATT 1994." The AB here finds that, for the Byrd Amendment payments to be legal, they have to belong to one of the categories of measures mentioned in Art. VI.2 GATT; they must hence take the form of either definitive antidumping duties, or provisional measures, or price undertakings. Since the Byrd payments 
do not fall under any of these three categories, they are illegal (a similar, but somewhat more involved reasoning is undertaken for the case of subsidies). ${ }^{3}$

\subsection{Discussion}

As mentioned above, the Panel found two reasons why the Byrd payments act "against" dumping in violation of Art. 18.1: one was that potential dumpers would choose to dump less in order to prevent the competitiveness of US firms being enhanced - what we for ease of exposition, will refer to as the competitiveness effect - and the other that exporters would dump less since the payments would encourage more antidumping filings, and support for such filings - to be denoted the filings effect. The $\mathrm{AB}$ hence accepts the Panel's reasoning concerning the competitiveness effect, but rejects the argument built on the filings effect.

In the following discussion, we make several claims. First, the $\mathrm{AB}$ treats in an incoherent manner the legal issues surrounding the two effects of the Byrd legislation that, in the Panel's view, violate Art. 18.1 $\mathrm{AD}$. In particular, had the $\mathrm{AB}$ applied to the competitiveness-effect argument the same type of reasoning that it applied to the filings-effect argument, it would then have rightly found the contested legislation to be perfectly consistent with US obligations under the WTO, as we conclude in Section 2.4.1 of this Chapter, below. Second, the AB's treatment of the competitiveness-effect argument is deficient, as shown below in Section 2.4.2: the $\mathrm{AB}$ does not make clear what is required for an economic theory to strike down legislation; it makes claims concerning economic effects without performing an economic analysis; moreover, its economic theory itself is questionable. Finally, the $A B$ de facto does not employ its own judge-made standard of review to strike down the legislation, which it has employed in previous cases when faced with claims concerning legislation's inconsistency with the WTO. Consequently, the AB (as well as the Panel) strikes down the Byrd Amendment on flimsy grounds, as we discuss in Section 2.4.3. Additionally, in the same Section, we go through the negotiating

${ }^{3}$ The same reasoning applies mutatis mutandis for the AB's findings in the context of the SCM. In the remaining part of this chapter, we will discuss only the AB's findings with respect to claims under the $\mathrm{AD}$ Agreement. Its findings are, in principle, identical with respect to claims under the SCM. We will refer to the latter only when necessary to explain issues that are specific to this Agreement. 
history to show that one can legitimately inquire into the actual ratio legis of Art. 18.1 AD, since its legislative intent is far from clear.

\subsubsection{The AB's incoherent treatment of dissuasive effects}

Consider first the AB's treatment of the Panel's competitiveness-effect argument. The $\mathrm{AB}$ accepts the claimed economic relationship; we will discuss infra its rationale for doing this. The $A B$ then argues that the Byrd Amendment is WTO-inconsistent, since it has the aforementioned alleged dissuasive effect on dumping, and this effect does not stem from one of the three instruments allowed under Art. VI GATT to dissuade dumping. This reasoning is also employed in the AB's discussion of whether the intent behind the legislation matters. On this score, the $\mathrm{AB}$ states:

... The text of the CDSOA provides sufficient information on the structure and design of the CDSOA, that is to say, on the manner in which it operates, to permit an analysis whether the measure is "against" dumping or a subsidy. Specifically, the text of the CDSOA establishes clearly that, by virtue of that statute, a transfer of financial resources is effected from the producers/exporters of dumped or subsidized goods to their domestic competitors. This essential feature of the CDSOA constitutes, in itself, the decisive basis for concluding that the CDSOA is "against" dumping or a subsidy_because it creates the "opposition" to dumping or subsidization, such that it dissuades such practices, or creates an incentive to terminate them.

( $\$ 259$, underlining added, footnote omitted)

That is, it suffices that the measure dissuades dumping for it to be "against" dumping.

Now, we turn to the AB's view on the filings-effect argument. It is not clear to us whether the $\mathrm{AB}$ accepts the view that, as a matter of economic implications, the Byrd scheme actually reduces the number of filings, and the support for filings. When later discussing the alleged violation of Art. 5.4 AD, the $\mathrm{AB}$ seems to accept a US claim that there are no such effects, partly since filings would typically be supported anyway. On the other hand, when discussing the filings effect, the $A B$ does not question the existence of the effect; if the $A B$ had found it entirely implausible, it would presumably have added this argument to its objection against the Panel's acceptance of the filings-effect argument. However, from the point of view of this discussion it does not matter whether the $A B$ believes in this effect or not, since the reason for rejecting the Panel's 
ruling is different: in its view, it does not matter whether there is a filings effect on dumping since

a measure cannot be against dumping or a subsidy simply because it facilitates or induces the exercise of rights that are WTO-consistent. The Panel's reasoning would give Article 18.1 of the Anti-Dumping Agreement and Article 32.1 of the SCM Agreement a scope of application that is overly broad ...

These lines, together with the example of legal aid (see below), are the whole explanation offered by the $\mathrm{AB}$ for the finding that the filings effect does not make the Byrd legislation illegal. Partly due to the marked terseness of this explanation, we must admit having severe difficulties understanding exactly what the $\mathrm{AB}$ means here.

First, a "textual" reading of this statement gives rise to several questions. For instance, the statement refers to "rights that are WTO-consistent." Does this mean that in the set of rights that the AB is discussing here, there are those that are WTO-inconsistent? And who has argued that the Byrd legislation is illegal by facilitating WTO-consistent rights, as the quote seems to suggest? These questions may perhaps arise due to unfortunate drafting. But it definitely seems odd to us that a court that normally puts heavy emphasis on the "ordinary meaning of words," interprets the term "against" such that a measure need not be "against" dumping even though it is specifically designed to dissuade dumping, and also has this effect. For some unknown reason, the $\mathrm{AB}$ here decides not to adhere to its principle of relying on the "ordinary-meaning-of-the-words" interpretation.

Second, and more importantly, we do not understand why the $A B$ does not apply the same type of test to the competitiveness effect that it uses to exonerate the filings effect. It indeed seems to us that such an argument could be as applicable in the context of the competitiveness effect: just as Members have the right to facilitate the filings of antidumping petitions under the WTO Agreement, they have the right to subsidize domestic firms. The Byrd Amendment can be seen as a vehicle for facilitating the exercise of this right, by providing a scheme for the distribution of funds. Of course, such subsidization is possibly actionable, but it is not illegal when measured against the background of the current SCM. It follows that there is no fundamental difference from the point of view of Art. 18.1 AD between the two sources of illegality found by the Panel. Just as the filings effect was exonerated under 
Art. 18.1 AD, since it facilitates the exercise of WTO-consistent rights, so should the competitiveness implication of the legislation be exonerated, removing the sole basis for the $A B$ to strike down the Byrd legislation.

Note that we are not arguing that it is necessarily unwarranted to treat the two alleged effects of the legislation differently in general. What we claim is that the $\mathrm{AB}$ has not convincingly explained why this should be done.

Third, as mentioned above, the $\mathrm{AB}$ uses a hypothetical program that provides legal aid to smaller firms for filing antidumping petitions, as an example to demonstrate the unreasonableness of using the filings effect as a basis to declare the Byrd legislation illegal. As quoted earlier:

\begin{abstract}
... the Panel's reasoning would imply that a legal aid program destined to support domestic small-size producers in anti-dumping or countervailing duty investigations should be considered a measure against dumping or a subsidy within the meaning of Article 18.1 of the Anti-Dumping Agreement and of Article 32.1 of the SCM Agreement, because it could be argued that such legal aid is a financial incentive likely to result in a greater number or applications, investigations and orders.
\end{abstract}

$(\S 258$, italics in original)

As can be seen, the $\mathrm{AB}$ does not explicitly state that a prohibition of such a hypothetical program would be an undesirable outcome, but we take this to be implicit in the statement quoted above. Now, we agree with the $\mathrm{AB}$ that it seems plausible that such a program would make import competing firms more willing to request anti-dumping measures, and that it would thus have a dissuasive filings effect, like that of the Byrd legislation. But it also seems likely that this legal aid program will give rise to a competitiveness effect. For instance, some of these firms will presumably file petitions regardless of such an aid program; but because of income flowing from the legal aid program, they can use the financial resources that they would have spent on lawyers to invest and thus enhance their competitiveness. As far as we can see, this line of reasoning is almost identical to the argumentation in the case of the Byrd payments. Hence, for exactly the same reason that the $\mathrm{AB}$ finds the latter illegal due to the competitiveness effect, it should find the legal aid program illegal as well.

\title{
2.4.2 The evidence for the existence of the competitiveness effect
}

The AB's finding of an illegality is based on a claim that the Byrd legislation impacts on the incentives to dump. Central to the dispute 
should therefore be the evidence before the $\mathrm{AB}$ that led it to strike down the legislation. In our view, the AB's treatment leaves a lot to be desired in this respect.

\subsubsection{No discussion of what should be required for an economic} theory to strike down legislation A distinguishing feature of the dispute is the fact that the AB's (as well as the Panel's) finding is not based on any empirical verification. Instead, the AB's whole case rests on an economic theory. The theory essentially goes as follows: recipients of Byrd payments are allowed to use these payments to become more competitive in the marketplace, and, as a result, exporters have incentives to dump less:

... the recipients of CDSOA offset payments are entitled to use this money to bolster their competitive position vis-à-vis their competitors...

( $\$ 255$, underlining added)

... foreign producers/exporters have an incentive not to engage in the practice of exporting dumped or subsidized products or to terminate such practices...

(§256, underlining added)

A fundamental conceptual issue that this raises is the question of what should be required of such an economic theory in order for it to serve as an appropriate basis for a finding of an illegality, in particular when striking down legislation as such. One can easily see that there are a number of important aspects involved. For instance, what degree of certainty should an adjudicating body have that the alleged effect will arise in some particular industry? How plausible should the theory be as a description of this industry? Another type of question is: to what extent does the alleged effect have to arise across industries in order for a finding of an illegality? This question seems especially pertinent in light of the fact that the issue at stake is legislation, and not only specific applications of legislation. The $A B$ has, in its own case law when distinguishing between mandatory and discretionary legislation, established the principle that, for legislation to be illegal as such, it must systematically require authorities to implement WTO-inconsistent measures. For the Byrd legislation to be condemned with this principle being respected, it must hence first be established that the Byrd legislation is mandatory, in the sense that the ratione materiae competent US authority has no discretion and must make the payments whenever the legislation's statutes are fulfilled, a position 
which seems reasonable. The second part is much more questionable, however: the $\mathrm{AB}$ must maintain that its theory is descriptive of the effect of the legislation across industries. As will be argued below, there are good reasons to believe that this is highly unlikely to be the case.

We thus find the $A B$ report wanting in its failure to discuss this basic question of what should be required in order for an alleged, but empirically unverified, theory to strike down legislation.

\subsubsection{The $\mathrm{AB}$ advances an economic theory but no economic} analysis The AB's theory is clearly a statement about the effect of the contested legislation on the conditions of competition. At the same time, the $\mathrm{AB}$ dismisses the need for an analysis of the conditions of competition. To repeat:

In our view, in order to determine whether the CDSOA is 'against' dumping or subsidization, it was not necessary, nor relevant, for the Panel to examine the conditions of competition under which domestic products and dumped/subsidized imports compete, and to assess the impact of the measure on the competitive relationship between them...

How does the $\mathrm{AB}$ then determine the economic effects of the legislation without undertaking an economic analysis? The $\mathrm{AB}$ here uses a type of language it has employed in the context of Art. III GATT disputes:

... An analysis of the term 'against', in our view, is more appropriately centred on the design and structure of the measure; such an analysis does not mandate an economic assessment of the implications of the measure on the conditions of competition under which domestic product and dumped/subsidized imports compete.

(\$257, underlining added)

The central concept of "design and structure" is given some precision in $\$ 259$, according to which

... [ $\mathrm{t}$ ]he text of the CDSOA provides sufficient information on the structure and design of the CDSOA, that is to say, on the manner in which it operates ... (underlining added)

Despite this reference to the revealing "structure and design" of the legislation, we simply fail to understand how an economic analysis of the competitive effects of the legislation can be avoided, when these effects are determined to be crucial to its illegality. Indeed, the $A B$ 
actually undertakes a very brief economic analysis itself, after having dismissed the need for the Panel to do this, when it claims that the transfer of financial resources will have a certain impact on pricing decisions by exporters. It might perhaps be claimed that the economic effects of the legislation are so obvious that there is no need for an analysis. But this does not seem to be the position of the $A B$ (even though we are uncertain about this). Instead, our reading is that there is some more fundamental reason why the "design and structure" of the legislation directly reveals to the $\mathrm{AB}$ its economic effects, but we do not understand what this is.

As a matter of fact, we do not understand the point of looking at the design and structure at all. The $\mathrm{AB}$ writes that:

...we believe it is necessary to assess whether the design and structure of a measure is such that the measure is "opposed to", has an adverse bearing on, or, more specifically, has the effect of dissuading the practice of dumping...

(§254, underlining added)

But why should one look at something as vague as the "design and structure" in order to assess whether the measure has certain effects? Why not look directly at the effects of the measure? We do not think that this is just a play with words. The $\mathrm{AB}$ somehow (and we do not understand why) seems to feel that, by concentrating on the "design and structure" of the measure, it can make a shortcut in the determination of the effects of the measure, thus avoiding having to undertake a more traditional economic analysis.

2.4.2.3 The AB's economic theory is questionable As pointed out above, we do not know what criteria the $A B$ believes should be fulfilled in order to strike down legislation, nor do we know how the $A B$ views the degree of generality of the competitiveness effect argument. All we know is that this argument suffices, in the AB's view. One possibility is that, in the AB's view, for the legislation to be illegal, it suffices that the alleged effect arises in certain markets. In this case, the AB's economic theory may be reduced to a weak statement:

"It is not completely unlikely (or it is likely) that the competitiveness effect is at play against some potential dumper in the US market."

If this is the correct interpretation of the AB's position, we can conclude that its economic theory seems acceptable without much further 
reasoning, since the competitiveness effect reasoning seems sufficiently plausible to arise at least somewhere. The problem with this interpretation is, however, that it relies on an extremely weak criterion to strike down the legislation. ${ }^{4}$

Another possibility might be that the $\mathrm{AB}$ believes that its theory is much more general. For instance, it might implicitly be concluding that:

"The competitiveness effect describes the typical (or average) reaction by potential dumpers in the US market."

If this is the AB's position, the lack of economic analysis is much more troublesome. In our view, there are then good reasons to believe that the claim is factually incorrect. At the very least, it is sufficiently questionable to need some serious justification, as we will show below. To simplify matters, we will discuss the theory's two parts separately, even though a more satisfactory analysis would take account of the interaction between the two.

Will the legislation lead to enhanced competitiveness of domestic firms? Central to any reasonable economic analysis of the legislation's effect would be the link domestic firms perceive between their actions and the payments. If payments are seen by these firms as windfall gains, that is, as effectively unrelated to their actions in their respective markets (but of course depending on their expressed support for AD investigations, as required by the legislation), standard economic reasoning would suggest that they have no effect on the competitiveness of domestic firms. The payments would then only increase firms' financial wealth, without affecting their profit-maximizing decisions with regard to pricing or investment, the argument roughly being that the latter depend on demand and production cost conditions, and not on the financial wealth of the firm. ${ }^{5}$ On the other hand, if firms perceive that the magnitude of the payments received are related to their pricing and investment decisions, the existence of the payment scheme may impact on domestic firms' behavior and thus their behavior vis-à-vis foreign competitors.

\footnotetext{
4 And, as will be shown infra, it also runs afoul of the $\mathrm{AB}$ case law on this score.

${ }^{5}$ Grossman and Mavroidis (2004) argue that the AB made a crucial mistake in the US Lead Bismuth II dispute by failing to appreciate a very similar type of distinction.
} 
One would also want to know the likely magnitude of any such effects. In order for the legislation to affect the investment and pricing decisions of domestic firms, those firms must believe that these decisions affect the amount of payments they will eventually receive. However, it seems plausible that such links must often be seen as very weak. To start with, whenever an individual domestic firm has a limited market share, the impact of its decisions on the funds eventually to be distributed is likely to be very small. There is also likely to be considerable uncertainty concerning the payments it will receive. The payments will be affected by how the legislation affects dumping decisions by foreign firms (since this will affect the amount of money being available for redistribution), as well as the decisions of other domestic firms (since this will affect claims for the available money). Without pretending to have undertaken a satisfactory economic analysis, we note that these observations suggest that the legislation should often be expected to have negligible impact on pricing and investment decisions.

Despite being central to an economic analysis of the impact of the legislation, how domestic firms view the link between their competitiveness-related decisions and the payments receives very little discussion by the $\mathrm{AB}$. The $\mathrm{AB}$ points out that the "qualifying expenditures" for which the Byrd payments are made must, according to the US legislation,

... be related to the production of the same product that is the subject of the related order or finding...

(§255, underlining added)

But there is no discussion of the nature of the requirement that expenditures must "be related to the production." The $\mathrm{AB}$ also points to the related aspect of the payments that, once received, firms are allowed to use the payments in whatever fashion they want. But while related, the question of what can be done with the payments once received is not the same as the question of what it takes to receive the payments in the first place. If anything, the fact that firms are free to do whatever they wish with the payments, suggests that the payments will not affect the market behavior of domestic firms: if investments into enhanced competitiveness are profitable, why would firms wait for the payments to undertake them? And to the extent that the dumping allegations occur in industries that are no longer internationally competitive, shouldn't one expect that firms in such industries may find it more profitable to invest outside the industry, in which case the 
payments would actually foster exit from the industry? If so, the legislation would presumably tend to serve as an encouragement to dumping, rather than the opposite.

Will the possible enhanced competitiveness of domestic firms induce less dumping? Let us now, for the sake of the argument, accept the first part of the competitiveness effect theory - the idea that the Byrd legislation will serve to enhance domestic firms' competitiveness - and consider its second part - the notion that the enhancement of the competitiveness of domestic firms induces exporters to dump less. It is here natural to distinguish between two types of potential effects resulting from the legislation.

First, in their pricing decisions, exporters must trade off gains from lower prices against the increased likelihood of triggering antidumping procedures. The immediate impact of the legislation on this balancing act seems likely to be similar to that which is suggested by the competitiveness effect claim: that the prospect of facing, on top of the antidumping duty, enhanced competitiveness among domestic firms, should tend to act as an extra inducement not to dump.

Again, the magnitude of this effect may be limited if there are several or more exporters. Each exporter would realize that, while the magnitude of the antidumping duties it may trigger is determined fully by its dumping margin, the link between its dumping margin and the enhanced competitiveness of domestic firms is likely to be much weaker. Also, the enhanced competitiveness will tend to affect all the exporters equally, which provides another reason why the competitiveness effect is likely to have a limited magnitude.

The effect just described builds on the impact of the threat of Byrd payments. But suppose that this effect is not sufficiently strong to entirely deter dumping, so that some payments will actually occur. What will be the effect of this? According to the AB's theory, firms will invest these payments in order to enhance their competitiveness, which would be reflected in a lowering of prices by domestic firms. The natural response of exporters would then be to also cut prices, in order to meet this intensified competition. However, if exporters cut their prices, they tend to dump more, and not less, as maintained by the $\mathrm{AB}$. It hence seems necessary to distinguish between the effects of the legislation when it deters dumping, from its effects when it does not suffice to deter dumping. Differently put, the legislation as such seems to dissuade dumping, while its application has the opposite effect. 
Conclusion concerning the AB's economic theory The point here is not to argue that it would be impossible to construct an economically reasonable argument why the payments may be used to enhance the competitiveness of domestic firms. Throwing the right ingredients into the brew (such as an imperfectly working capital market and limited access to outside investment opportunities), one could indeed construct such arguments. $^{6}$ Given the size of the toolbox of present day economics, it is possible to construct a theoretically unobjectionable argument to show just about anything, so something more is needed in order for a theory to be of practical interest: it requires arguments for why the theory is a plausible description. Nor do we maintain that the $\mathrm{AB}$ 's conclusion that the overall effect is to discourage dumping is wrong - this we simply do not know. Instead, we believe that the links between transfer payments and intensified competition, as well as between intensified competition and disincentives to dump, are much more complex than what seems to be acknowledged by the AB. There are also reasons to suspect that there are other economic implications of the legislation that the $\mathrm{AB}$ neglects. ${ }^{7}$ Just a scratching of the economic surface of the Byrd legislation suggests to us that the AB's argument is highly questionable, if meant to represent "typical" implications of the contested legislation, or at the very least, needs significant support in terms of economic analysis. We therefore find it remarkable that the $\mathrm{AB}$ explicitly states that an economic analysis is not necessary at the same time that it makes its pronouncement on the effect of the legislation on competitive conditions. We believe that the $\mathrm{AB}$ in this central respect applied too low a standard of review.

${ }^{6}$ A different line of defense of the claimed competitiveness effect would be to argue that it is not really the competitiveness of firms that is enhanced, but rather the depth of their financial pockets, and that with the payment they can escape bankruptcy. This might plausibly be the case in certain circumstances. But it begs the question as to why the firms do not use the financial resources to invest in more profitable activities than those in the industry.

${ }^{7}$ For instance, as argued by Collie and Vandenbussche (2004), an essential aspect of the Byrd legislation is that it is likely to give a larger weight to tariff revenue in the government's duty determination, since the revenue now accrues to the lobbying industry, rather than the general taxpayer. Consequently, it may induce the government to use the leeway it has in determining the level of $\mathrm{AD}$ duties, to increase these as a result of the legislation. This raises the intricate question of whether the adjudicating bodies should take into account such effects. (The effects referred to here differ from those affecting the willingness of firms to file and support $\mathrm{AD}$ complaints that the $\mathrm{AB}$ dismissed as a basis for a finding of an illegality, arguing that the United States was in this respect only exercising its lawful rights.) 


\subsubsection{The $\mathrm{AB}$ violates its own standard for striking down} legislation We attempted to demonstrate above that the competitiveness effect, as argued by the $A B$, cannot lightly be assumed to be the typical effect of Byrd payments. We should recall, however, that the legal challenge in the instant case is against legislation and not an application thereof. According to the standing case law, for an article of legislation to the be deemed to be WTO-inconsistent, it must be shown to consistently yield WTO-inconsistent outcomes. This has not been the case with respect to the Byrd legislation.

This discussion has, of course, to do with the distinction between mandatory/discretionary legislation and to what extent the latter can be properly challenged before a WTO adjudicating body. The earlier case law suggested that this was not the case. The subsequent case law has led to misunderstandings in the literature as to what the appropriate standard in similar cases actually is. We will try to briefly review the more recent case law and show that it should not be understood to condone a finding of illegality in cases where, as in the instant case, a piece of legislation only in certain circumstances could lead to a behavior inconsistent with the WTO.

In its US - Section 211 Appropriations Act opinion, ${ }^{8}$ the $\mathrm{AB}$ distanced itself from the manner in which the Panel before it had applied the distinction between mandatory and discretionary legislation. In the $A B$ 's view this was a functional distinction that was not to be applied in a mechanistic fashion. However, the AB stated (\$259) that

...where discretionary authority [was] vested in the executive branch of a WTO Member, it [could not] be assumed that the WTO Member [would] fail to implement its obligations under the WTO Agreement in good faith...

Its latest pronouncement was made in the US - Corrosion-Resistant Steel Sunset Review dispute in which the $\mathrm{AB}$ addressed a US practice established in the context of that country's review of the need for a continued imposition of antidumping duties. ${ }^{9}$ The $\mathrm{AB}$ did state that, in certain circumstances, practices can also be challenged, but not that the mandatory/discretionary legislation is obsolete. The AB argued ( $(89)$ that Panels are not

...obliged, as a preliminary jurisdictional matter, to examine whether the challenged measure is mandatory...

\footnotetext{
${ }^{8}$ See WTO Doc. WT/176/AB/R. ${ }^{9}$ See WTO Doc. WT/DS244/AB/R.
} 
However, the $\mathrm{AB}$ did maintain (\$89) that this distinction is fully pertinent when it comes to assessing whether the measure at hand is (or is not) WTO-consistent. In the case at hand, confronted with evidence suggesting that the contested US Bulletin was codifying practice that led to the same (WTO-inconsistent) outcome in dozens of cases (and with no evidence to the contrary), the $\mathrm{AB}$ held that the US practice was WTO-inconsistent although the Bulletin in which it was codified was not legally binding on the US administration.

These two cases suggest that non-binding instruments as well can be challenged before the WTO, but they have to predictably lead to WTO-inconsistent results. In other words, the likelihood that an illegality will be committed does not suffice for a piece of legislation to be adjudged WTO-inconsistent.

The most recent pronouncement on this score is evidenced in the panel report Korea - Commercial Vessels ${ }^{10}$ where the Panel, citing the case law mentioned supra, explicitly upheld the distinction between mandatory and discretionary legislation and refuted an argument advanced by the European Community (EC) to the effect that there had been a revirement de jurisprudence on this score as a result of the $\mathrm{AB}$ jurisprudence in US - Corrosion-Resistant Steel Sunset Review $(\$ \S 7.60-7.63)$.

It follows that in the present case, the $\mathrm{AB}$ consequently failed in two respects: one the one hand, it applied a deficient economic analysis to verify whether the Byrd payments had the alleged competitiveness effect; on the other, it misapplied its own standard for finding a violation.

\subsubsection{Some reasons suggesting a limited intended ambit of Art. 18.1 AD}

We have thus far considered the internal consistency of the AB's reasoning, and the evidentiary standard it implicitly applies. We will now turn to a more general interpretation of Art. 18.1 AD, and the question of its intended role in the Agreement. We will here make a few reflections suggesting that the adjudicating bodies may have given the provision an overly wide ambit.

Following its US - AD Act of 1916 jurisprudence, the $\mathrm{AB}$ has understood Art. 18.1 AD to be a self-standing provision: there is no requirement that a Member have violated any one of the obligations

10 See WTO Doc. WT/DS273/R of 7 March 2005. 
embedded in Arts. 2-17 AD, for a violation of Art. 18.1 AD to occur. ${ }^{11}$ Indeed, in the present case, the $\mathrm{AB}$ even rejects the Panel's findings under Art. 5.4 AD and argues that Art. 18.1 AD can by itself signal the inconsistency of a specific measure with the AD Agreement. In our view, the $A B$ does not provide an adequate motivation for this farreaching interpretation of Art. 18.1.

It would seem natural, when confronting an alleged violation of Art. 18.1 $\mathrm{AD}$, to start by observing that the interpretation of the provision is far from self-evident. The requirement that Members should not take actions against dumping that are not in accordance with the GATT 1994, seems, at least under a textual reading, superfluous, since no actions should be taken in violation of the GATT 1994, regardless of whether addressing dumping or not. The footnote explaining that " $[\mathrm{t}]$ his is not intended to preclude action under other relevant provisions of the GATT 1994, as appropriate" is no doubt meant to limit the unclear scope of the requirement in the main text, and as such does not add much precision to the provision, nor does the qualification "as appropriate" add clarity. This is not to say that it is impossible to find a meaning by "reading between the lines." But Art. 18.1 $\mathrm{AD}$ is far from being a self-interpreting provision, and its implementation has to take this into account.

Since a purely textual interpretation of Art. 18.1 is difficult, the context, and the object and purpose, must play a prominent role in the interpretation of its ambit. One can here note that the provision is given a rather obscure place in the Agreement: it is put together with some other diverse obligations in a "Final Provisions" article, toward the end of the Agreement. This placement does not seem to suggest that the provision is intended to have a very important role. The provision rather seems to be one of several "leftovers" from the negotiation table.

Turning to the preparatory work that led to the inclusion of the provision, a version of this provision appeared in the original GATT/ITO discussions. Art. IV.7 of the 1947 version of the GATT reads as follows:

No measures other than anti-dumping or countervailing duties shall be applied by any contracting party in respect of any product of the territory of any other contracting party for the purposes of offsetting dumping or subsidization.

11 Assuming that there is an overlap between Arts. 1 and 18.1 AD. 
This provision seems to underline the idea that dumping should not be dissuaded through other means than $\mathrm{AD}$ duties.

As a matter of positive law, however, this provision never saw the light of day, since it was not incorporated in the final Art. VI GATT 1947. Oddly, we find the only expressed understanding for its rationale in a statement justifying its exclusion: The sub-committee dealing with the final draft of the GATT decided to delete the provision, but it

...did so with the definitive understanding that measures other than the compensatory anti-dumping or countervailing duties may not be applied to counteract dumping or subsidization except in so far as such other measures are permitted under other provisions of the Charter. ${ }^{12}$

This passage denotes a rationale for this provision that, to some extent, has been overtaken by the footnote to Art. 18.1 (footnote 24) in the current $\mathrm{AD}$ Agreement: in principle, parties should address dumping only through anti-dumping measures, and subsidies only through countervailing duties.

We find the provision in Art. 18.1 AD for the first time in the Tokyo Round AD Agreement (as Art. 16.1), but we have not been able to uncover even a trace of its negotiating history, either in the Tokyo Round, ${ }^{13}$ or when it was incorporated into the Uruguay Round AD Agreement. The absence of any meaningful discussion on the rationale for this provision probably indicates a combination of two facts: first, that the Tokyo and Uruguay Round negotiators accepted the rationale offered at a previous stage, and, second, that the provision was not seen as being very important to the Agreement. It seems that the provision, when read with others (for example, Art. XIX GATT dealing with safeguards action) helped clarify the ambit of permissible action undertaken under contingent protection instruments.

The analysis above suggests that at least two rationales could be advanced as plausible explanations for the advent of Art. 18.1 AD: it could be that negotiators agreed with the original rationale (offered already in the preparatory work from 1947); or, it could be that the

${ }^{12}$ See the Archives, Reports of committees and principal sub-committees, Interim Commission for the ITO, Geneva, September (1948) at p. 74, §25.

${ }^{13}$ Indeed, a series of documents reflecting the negotiating history refers to the provision in terms more or less identical to the final draft terms, without referring at all to the rationale for its inclusion, see GATT Docs. MTN/NTM/W/168 of 10 July 1978, W/208 of 15 December 1978, and W/210 of 19 December 1978. 
same provision kept its value in order to address practices that emerged post 1947, and that could not have been anticipated.

A good illustration of what the provision may have aimed at is probably the "anti-circumvention" provision in EC antidumping law. In the GATT years, the EC was condemned for using the anticircumvention provision in its antidumping legislation to impose duties on finished items (cars), parts and components of which were allegedly dumped: Art. 13.10 of the EC antidumping regulation (2423/88) constituted the subject matter of the litigation and it relevantly provided:

Definitive anti-dumping duties may be imposed, by way of derogation from the second sentence of paragraph $4(\mathrm{a})$, on products that are introduced into the commerce of the Community after having been assembled or produced in the Community ...

Such use was deemed necessary by the EC, since, otherwise, it would be left without any weapons to counteract this form of dumping (the EC namely could not satisfy the "likeness" element, as it appears in the injury analysis, since a part of a car and a car are not like products).

During the Panel proceedings in EEC - Regulation on Imports of Parts and Components that were requested by Japan, the EC did not advance detailed arguments in defense of its law under Art. VI GATT, but stated that were the panellists to take the view that its provision was consistent with Art. VI GATT, it would not disagree. We quote from the Panel's report: ${ }^{14}$

The Panel further noted, that the United States, as an interested third party, had argued that Article VI of the General Agreement provided to a certain extent a legal basis for measures to prevent what it considered to be circumvention of anti-dumping duties. At one point in the proceedings the EEC stated that, if the Panel were to find that the anticircumvention duties were justifiable under Article VI, 'it would not disagree' with such an approach... However, the EEC presented no arguments in support of a justification of its measures under Article VI.

The EC measures were found to be in violation of the GATT anyway (Art. III), without the Panel ever discussing their consistency with Art. VI GATT. This issue was left in limbo. During the Uruguay Round negotiations, negotiators could not agree on this issue and therefore

14 GATT Doc. BISD 37S/132ff., adopted on 16 May 1990. 
referred it to the WTO Anti-Dumping Committee for further deliberations. But no action has been taken on this front since then. As a result, it is still an open question whether anti-circumvention provisions are consistent with Art. VI GATT. However, the fact that a formal decision was taken during the Uruguay Round suggests that, at least on January 1, 1995, anti-circumvention provisions were very much a concern.

To conclude, there are several reasons to suggest that it is far from clear what the rationale behind Art. 18.1 AD actually is. When confronted with so much uncertainty, we would expect the $A B$ to at least pay some attention to the circumstances surrounding the negotiation of this provision, and not, instead, jump to conclusions on its ambit based on an obscure text.

\section{Does the Byrd Amendment violate Arts. 5.4 AD and 11.4 SCM?}

The second issue raised in the appeal is whether the Byrd Amendment violates Art. 5.4 AD and the identical provision Art. 11.4 SCM. These provisions regulate the standing requirements for a petition to be examined by a domestic investigating authority entrusted with the administration of antidumping and subsidies/countervailing laws. Article 5.4 AD reads:

An investigation shall not be initiated pursuant to paragraph 1 unless the authorities have determined, on the basis of an examination of the degree of support for, or opposition to, the application expressed by domestic producers of the like product, that the application has been made by or on behalf of the domestic industry. The application shall be considered to have been made "by or on behalf of the domestic industry" if it is supported by those domestic producers whose collective output constitutes more than 50 per cent of the total production of the like product produced by that portion of the domestic industry expressing either support for or opposition to the application. However, no investigation shall be initiated when domestic producers expressly supporting the application account for less than 25 per cent of total production of the like product produced by the domestic industry (footnote omitted).

\subsection{The divergent views of the panel and the $A B$}

The $\mathrm{AB}$ explains its understanding of the Panel's findings that the Byrd Amendment violates Arts. 5.4 AD and 11.4 SCM in the 
following terms:

The Panel found that the CDSOA provides a financial incentive for domestic producers to file or support applications for the initiation of anti-dumping or countervailing duty investigations, because offset payments are made only to producers that file or support such applications. According to the Panel, the CDSOA will result in more applications having the required level of support from domestic industry than would have been the case without the CDSOA, and that "given the low costs of supporting a petition, and the strong likelihood that all producers will feel obliged to keep open their eligibility for offset payments for reasons of competitive parity, ... the majority of petitions will achieve the levels of support required" under Article 5.4 of the Anti-Dumping Agreement and Article 11.4 of the SCM Agreement.

(§277, italics in original, footnote omitted)

The Panel hence argues that the Byrd Amendment violates this provision, by making the quantitative test it requests meaningless.

The $\mathrm{AB}$ starts its examination of the Panel's argument by emphasizing that it does not accept the Panel's sole focus on the "object and purpose" of Arts. 5.4 AD and 11.4 SCM. Beginning with a textual analysis, it notes that Arts. 5.4 and 5.11 AD do not require authorities to look at the motives for firms' support for applications (something the Panel would most likely also agree with):

... those provisions require no more than a formal examination of whether a sufficient number of domestic producers have expressed support for an application...

... it is the "quantity", rather than the "quality", of support that is the issue.

The $\mathrm{AB}$ thus concludes that the text of Arts. 5.4 AD and 11.4 SCM does not support the Panel's reasoning.

Turning to the Panel's discussion on the "object and purpose" of these provisions, the $\mathrm{AB}$ dismisses the Panel's finding of an illegality on the basis of four arguments (the relative importance of which is not revealed). The $\mathrm{AB}$ argues, first, that the Byrd payments do

... not change the fact that investigating authorities are required to examine the "degree of support" that exists for an application and that an application shall be considered to have been made "by or on 
behalf of the domestic industry" only if sufficient support has been "expressed"...

Hence, the presence or absence of the Byrd payments does not change, in the AB's view, the legal nature of the duty bestowed upon the United States to ensure respect of the statutory thresholds. Second, when performing this task, investigating authorities are not required by law to enquire into the motives of particular economic operators to support a petition (\$291). Third, the challenged payments do not necessarily entail coercion to support filings; economic operators are still free to choose whether they will support a petition or abstain from doing so (§293). Fourth, empirical evidence from the United States suggests that the Amendment has not had the effect of increasing the number of initiations of investigations, since the United States argued that it was rare for domestic producers in the United States not to have sufficient industry support anyway and no counterargument to this proposition was raised. On the basis of these observations, the $A B$ reverses the Panel's determination, and finds that the Byrd payments do not violate the "object and purpose" of Arts. 5.4 AD and 11.4 SCM.

The Panel also found that the United States had not acted in good faith, by rendering the substantive provision in Arts. 5.4 AD and 11.4 SCM a mere formality which would always be complied with as a result of the financial incentives provided to US domestic industry to support petitions to impose antidumping or countervailing duties.

The $\mathrm{AB}$ rejects this reasoning. It acknowledges the relevance of the good faith principle in the WTO legal order, by pointing to prior jurisprudence which made reference to it (\$296). But the AB also maintains that a violation of the good faith principle requires more than a simple demonstration of a violation of a WTO provision (\$298), and it concludes, without further explanation, that it does not share the Panel's view that the United States had not acted in good faith.

\subsection{Discussion}

We agree with the $\mathrm{AB}$ that a textual reading does not support a complaint under Art. 5.4 AD or 11.4 SCM. We are less convinced by the analysis of the "object and purpose" and "good faith" argument, however. 
Looking at the "structure and design" of the legislation, it is hard to come to any other conclusion than that the sole purpose of the Byrd Amendment, is to encourage firms to support filings for antidumping investigations. Indeed, this feature importantly contributes to why it is a "specific" action against dumping. But, as far as we can see, the AB somehow sidesteps a direct confrontation with this central aspect of the legislation, in its analysis of how it squares with the "object and purpose" of Arts. 5.4 AD and 11.4 SCM, and in the dismissal of the good faith argument.

It seems reasonable to assume that these provisions were meant to have some practical significance, and in particular, that the specific levels for support that are stipulated in Arts. 5.4 AD and 11.4 SCM presumed that governments did not actively affect the process whereby the support is expressed. ${ }^{15}$ Presumably, the support should be "real." It also seems reasonable to assume that the Byrd legislation provides a significant incentive to support filings. Consequently, it seems inescapable to conclude that the legislation adversely affects the intention behind Art. 5.4 AD, rendering it a meaningless hurdle against investigations being initiated with very limited industry support.

One natural possibility would thus be to see the Byrd Amendment as undermining the "object and purpose" of Art. 5.4, as argued by the Panel. But the $\mathrm{AB}$ dismisses this on what we see as flimsy grounds.

First, the argument in $\$ 279$ that the existence of the Byrd legislation does not change the US authorities' duty to examine the degree of support that exists for an application, is hard to understand. The most sense we can make of it is to interpret it as saying that, in practice, the authorities have to change their method of counting the support for an application after the adoption of the contested legislation. Methods that sufficed in its absence are no longer useful in order to reveal whether the "true" support exceeds, for instance, 50\%. We would be sympathetic to an argument along these lines, at least as a matter of theory. However, nothing in the $\mathrm{AB}$ report suggests that this is what it meant, and we can only understand the AB's argument as a formalistic reply without any clear implication for how the investigation concerning the support for applications should be done in practice.

Second, we also find the argument in \$291, that authorities do not have to look into the motives of firms supporting applications,

15 This conclusion is reinforced by the fact that the AD Agreement provides for the possibility that a WTO Member can ex officio initiate an antidumping investigation (see infra). 
to be quite uninformative. The practical problems with this approach would, of course, be almost insurmountable, as pointed out by the AB. But this does not suffice as an argument to allow the test required under Art. 5.4 AD (and Art. 11.4 SCM) to become a mere formality, without at least acknowledging the problems that the $\mathrm{AB}$ encounters in giving it a meaningful interpretation. To our way of thinking, the $\mathrm{AB}$ fails to properly account for the context of this legal provision. A WTO Member can, of course, initiate an investigation ex officio. Doing so, it does not need any input from the private sector. Since governments have the institutional possibility to act ex officio, the "upon-request" route must indeed be the outcome of an autonomous private decision to this effect, and not a government-mandated/ influenced decision. We would here have welcomed a discussion of "where to draw the line" in terms of government involvement in the formation of private support to a petition. By referring to the irrelevance of motives, the $\mathrm{AB}$ closed outright the door to a legal review of what the bona fide implementation of Art. 5.4 AD (and Art. 11.4 SCM) actually amounts to.

Third, the $\mathrm{AB}$ seems to contest the empirical claim that the Byrd legislation induces firms to support more applications, when it maintains that all applications would find support even in its absence. This latter argument is based on the US claim that it is "rare" that support is missing, and that during one particular year (the one before the implementation of the legislation), all applications were supported. This reasoning raises a number of questions. What is "rare" $-5 \%$ of cases, $15 \%$, or what percentage of cases? How "rare" is acceptable? How representative was the particular year that the United States refers to? Why does the legislation include a requirement that firms have to have supported filings in order to be eligible for payment, if there is no scope to increase such support? After all, legislators should have realized that this would be a highly contentious aspect of the legislation.

It should also be noted that the US argument sidesteps an important aspect by essentially stating that, given that an application is filed, it is typically supported even absent the Byrd legislation, and that the legislation consequently does not change the picture at all. But there is presumably a self-selection with regard to applications. If firms know that an application will not find support, they will probably not set it in motion. What the US argument thus fails to account for is how the Byrd legislation influences the propensity to file applications. 
Turning to the "good faith" argument we can only note that the $\mathrm{AB}$ does not in any way explain its position. It simply states that it does not share the view of the Panel, since a "good faith" argument needs to be based on something more than an illegality. The $\mathrm{AB}$ does not specify in any way what (or how much) more is required for such a violation to occur.

To conclude, we believe that Arts. 5.4 AD and 11.4 SCM were inserted to reduce the risk of "abusive" initiations of investigations, since initiations of investigations, irrespective of their final outcomes, can have a negative impact on the exporters. It is clear from the "design and structure" of the Byrd legislation that it is meant to influence filings for antidumping petitions, and that it has such an effect. In our view, it is therefore unsatisfactory that the $\mathrm{AB}$ did not sufficiently address the Arts. 5.4 AD and 11.4 SCM claim under this prism. Although not a necessity, it seems much more plausible to claim that the typical effect of the legislation is to stimulate filings or support for filings, than to claim that the competitiveness effect argument describes the typical reaction on behalf of potential dumpers.

\section{Other possible lines of attack on the Byrd legislation}

As discussed above, the $\mathrm{AB}$ deals with allegations that the Byrd Amendment violates Arts. 18.1 AD and 5.4 AD (and the corresponding provisions in the SCM). We will here discuss some other potential lines of attack. Of course, the $\mathrm{AB}$, due to the non ultra petita maxim, can respond only to claims made by the parties to the dispute.

First, a natural objection to the legislation seems to be that it provides subsidies to the domestic industry. WTO Members importing from US companies that have benefited from Byrd payments could therefore have reacted by imposing countervailing duties (CVDs), provided the other conditions for this imposition were met. But one could possibly also make an argument that the Byrd payments, being subsidies, can be counteracted irrespective of whether the beneficiaries sell in the US market or abroad. The requirements in Arts. 1 and 2 SCM concerning the existence of a specific subsidy seem to be met: since money leaves the US budget, and goes to specific companies, the payments are specific. With regard to "benefit," the WTO case law does not demand a sophisticated analysis. Under the so-called "private-investor" test, the WTO case law indicates that the term captures any action mentioned under Art. 1.1 SCM that might even potentially and indirectly affect the 
decisions by the beneficiaries. Consequently, it is not necessary that the effects of the subsidies in terms of pricing decisions be shown, for a benefit to be deemed conferred. It suffices that the beneficiaries have received something from the government which they would not have received from the market. In the case of the instant dispute, domestic firms received the Byrd payments, and the WTO judge had no need, according to case law, to ask how these payments affected exporters. ${ }^{16}$ Since the subsidy was not prohibited, it must have been actionable. To our knowledge, only Mexico made the argument concerning subsidization before the Panel, but did not pursue it to its logical conclusion.

There are limits, however, as to how much can be achieved through this legal argument. Assuming the money has been transferred to specific companies, a successful complainant would need to demonstrate adverse effects (Art. 5 SCM) or serious prejudice (Art. 6 SCM) resulting from the payments at hand. In short, the complainant would need to show that as a result of the subsidization, it suffered loss of market share, either in the US or in a third market.

What we have described so far, however, is not a line of attack against the Byrd legislation as such, but rather an attack against actual payments. Attacking the Byrd legislation as such under the SCM will present potential complainants with a mountain to climb.

To start with, potential complainants would have to satisfy the specificity requirement, since, in principle, Byrd payments are generally available. However, payments will be made to companies operating in the same sector where an antidumping investigation will be initiated each time. Hence, an argument can be made that, although payments are generally available, the intent of the legislator is to limit, each time payments occur, the beneficiaries to a particular sub-set of all potential

16 Grossman and Mavroidis (2004) argued that the only understanding of the term "benefit" in Art. 1.1 of the SCM that is consistent with what seems to them the aims and objectives of those who drafted the Agreement, is that it must, somehow, affect the competitive conditions of the players in a given market. They view the main objective of the SCM to be to discourage subsidies that threaten harm to competing producers in importing countries. It therefore makes little sense to interpret "benefit" in terms of the financial wealth of the owners of a firm. Rather, the potentially adverse effects of a subsidy on producers in an importing country can be avoided only if a subsidy is deemed to exist whenever a government's financial contribution impacts the competitive situation in an industry. But for better or for worse, given the case law understanding of the term "benefit," it is not necessary to consider the effects on competition in order to classify Byrd payments as a subsidy in the sense of the SCM. 
beneficiaries. Legislative intent is probably the most appropriate criterion to show whether a subsidy is de facto specific. On the other hand, there is no guarantee in the Byrd legislation that Byrd payments will eventually take place. If at all, the only guarantee is that an antidumping investigation will be launched (assuming that the statutory thresholds will always be met as a result of the incentive to support petitions, an assumption unsupported by empirical evidence, as we have already stated above). The "subsidy" that will always be provided is hence the antidumping investigation itself. ${ }^{17}$ One could argue that antidumping investigations (even those that do not lead to the imposition of duties) have measurable effects in the market which favor the domestic industry, so a precise legal argument will have to be drafted along these lines. ${ }^{18}$ Were, however, this avenue to be privileged, the complainant will have to control for the fact that it will be breaking new ground arguing that the initiation of an antidumping investigation is itself a subsidy since it represents a cost to government which confers an advantage to specific beneficiaries.

A non-violation complaint is a second possibility. The legal argument here would be that, following the change of concessions, an action occurred (Byrd legislation) that could not have been reasonably expected and that resulted in nullification and impairment of benefits for the complaining party. The complaining party would have an easy task to demonstrate that the Byrd Amendment could not have been reasonably expected: as established in the Kodak - Fuji report (WT/DS44/R), in case an action takes place after a concession has been negotiated, there is a presumption that the complainant could not have reasonably anticipated it. ${ }^{19}$ The prima facie more difficult task would be to show nullification and impairment. One possibility would be for the complainant to demonstrate that its exporters are, because of the Byrd Amendment, subjected to a higher number of antidumping investigations than they would be otherwise (in the absence of the legislation). The nullification and impairment would materialize not in the higher number of investigations per se, but in the likelihood to face antidumping duties more frequently.

${ }^{17}$ We acknowledge our discussions with Alan Sykes on this issue.

${ }^{18}$ One could also argue that the subsidy is exhausted in the payment, without inquiring into the nexus between the payment as such and its origins in the antidumping investigation.

19 This opinion was upheld by the $\mathrm{AB}$ in its Asbestos jurisprudence; see WTO Doc. WT/DS135/AB/R. 
A third avenue for attacking the Byrd legislation would be to focus on its effect on the competitive position of exporting firms (rather than on their incentives to dump, which is at the core of the Panel's Art. 5.4 $\mathrm{AD}$ argument). In the dispute at hand, the $\mathrm{AB}$ makes explicit reference to all the interpretative tools referred to in the Vienna Convention on the Law of Treaties (VCLT) and to which it has made reference in all its case law so far: the text, context, object, and purpose of the treaty. Yet, it once again fails to take proper account of the context, which denotes through which specific means, the specific ends assigned to the treaty-regime will be achieved. An alternative way in which the Byrd Amendment could be found illegal, would thus put more emphasis on the context of the AD Agreement. ${ }^{20}$

The context of the Agreement is at least the rest of the Agreement, legally speaking. The most important provision to understand the function of the AD Agreement is Art. 3.1 AD (Arts. 5 and 15.1 SCM). There it is clearly stated that WTO Members are allowed to counteract dumping (or subsidies) provided that they demonstrate that their domestic industry producing the like (to the dumped/subsidized) product has suffered injury as a result of dumping (subsidy). The purpose is therefore not to prevent dumping from occurring - had this been the case, it could have been declared illegal as such - but to allow importing countries to insulate themselves from the effects of dumping.

How far, then, can a country go in order to insulate itself? The importing country has to establish that material injury has occurred as a result of the dumping. But once this is done, the magnitude of the permissible duty is independent of the magnitude of the injury. Instead, the maximum antidumping duty is the full dumping margin. But, any worsening of the competitive position of the dumping firm beyond this maximum amount is not permissible under the $A D$ Agreement.

Consequently, Byrd payments would affect the competitive position of exporting firms, for two reasons: First, dumping firms would face more severe consequences from their dumping than what is intended under the AD Agreement. Not only would the full dumping margin be offset through the duty, but also, on top of this, the dumping firms would face a deterioration of their competitive position due to the payments. As far as we can see, this "over-punishment" of dumping

20 The following borrows from Bhagwati and Mavroidis (2004). 
firms would be a sufficient ground to declare the Byrd Amendment illegal under the $\mathrm{AD}$. Of course, this argument relies on the assumption that the payments de facto change the competitive position, which as a matter of economics is far from being a foregone conclusion, as discussed above.

Second, enhanced competitive positions of domestic firms will not only affect dumping exporters, but also other exporters to the market, and the detrimental effect on these exporters may possibly serve as a basis for a finding of an illegality under the SCM.

\section{Concluding remarks}

Our main observations concerning the $\mathrm{AB}$ 's determination in the Byrd legislation dispute have been the following:

First, we believe that the $\mathrm{AB}$ is inconsistent in its treatment of the two reasons advanced by the Panel to support its findings that the Byrd legislation violates Art. 18.1 (and 32.1 SCM). Had the AB applied the same criterion to the competitiveness effect argument as it applied to the filings effect argument, it would not have found the contested legislation to be WTO inconsistent.

Second, the economic theory that the $\mathrm{AB}$ uses for striking down the legislation is inadequately motivated, and it is not clear how general the $\mathrm{AB}$ believes the theory to be.

Third, we doubt the validity of the theory, if it is meant to describe the typical impact of the contested litigation across industries.

Fourth, the $\mathrm{AB}$ strikes down the legislation as such on much weaker grounds than what it has established as a requirement in its case law.

Fifth, we believe that the $\mathrm{AB}$ should have undertaken a more comprehensive discussion of the claims under Art. 5.4 AD (and 11.4 SCM).

Finally, with regard to the outcome of the dispute, we believe that the reasons advanced by the $\mathrm{AB}$ do not suffice to establish that the legislation is inconsistent with Art. 18.1 AD (and 32.1 SCM). It seems to us that the question of whether the Byrd legislation violates Art. 5.4 AD (and Art. 11.4 SCM) is a more promising avenue for establishing an illegality: the text would give only very limited support for such a finding, but the legislation is likely to have the effect of rendering the test prescribed in these provisions meaningless, and it therefore seems to violate the object and purpose of the provision. 


\section{Post scriptum}

Remarkably, a more recent Panel (European Communities - Measures affecting trade in commercial vessels, WTO Doc. WT/DS301/R of 22 April 2005), when confronting the issue of the interpretation of Art. 32.1 SCM, seems to follow a different path from the one taken by the $\mathrm{AB}$ in the instant case. Delving into the negotiating history of this provision, it reaches the conclusion (as we also do) that this provision was originally meant to ensure that GATT contracting parties will not use measures other than, say, antidumping, to counteract dumping, unless such measures are permitted under the GATT (footnote 326 in the report, op. cit.). It then goes on to

... conclude that a subsidy provided in response to another Member's subsidy - that is to say, a counter-subsidy - will not, merely because of its impact on conditions of competition, constitute specific action against that subsidy and therefore be proscribed by the SCM Agreement. Rather, there must be some additional element, inherent in the design and structure of the measure, that serves to dissuade, or encourage the termination of, the practice of subsidization.

(§7.164, op. cit., italics in the original)

The reason for this conclusion is that

... if the mere fact that a subsidy granted by a Member to its domestic producers mitigates, or is intended to mitigate, the competitive impact of a subsidy granted by another Member to its domestic producers were sufficient to treat the subsidy granted by the first Member as action 'against' the subsidy of the second Member, this would create a new type of substantive disciplines on the provision of subsidies in addition to the disciplines already contained in Parts II and III of the SCM Agreement. Subsidies that in themselves are not prohibited because they are not subsidies of the kind covered by Article 3, and which do not necessarily even produce the effects that are the basis for a successful challenge under Articles 5 and 6 of the SCM Agreement, would nevertheless be prohibited because they are granted in reaction to subsidies of other Members. The Panel considers it unlikely that the drafters, having created a structure for the Agreement under which prohibited subsidies are regulated by Part II of the Agreement and actionable subsidies by Part III, would have then inserted a very significant additional prohibition in the concluding provisions of the Agreement. 
It should be noted that the challenged action in this ship-building case bears a striking similarity to the Byrd Amendment: the European Community designed a device to subsidize its domestic producers each time Korea would subsidize its own producers in the ship-building sector.

\section{References}

Bhagwati, J. and Mavroidis, P. C. (2004). Killing The Byrd Amendment With The Right Stone, World Trade Review 3: 119-127.

Collie, D. R. and Vandenbussche, H. (2004). Anti-dumping Duties and the Byrd Amendment (mimeo).

Grossman, G. and Mavroidis, P. C. (2004). United States - Imposition of Countervailing Duties on Certain Hot-Rolled Lead and Bismuth Carbon Steel Products Originating in the United Kingdom: Here Today, Gone Tomorrow? Privatization and the Injury Caused by Non-Recurring Subsidies. In H. Horn and P. C. Mavroidis, eds., The American Law Institute Reporters' Studies - The WTO Case Law of 2001. Cambridge University Press, Cambridge, UK. 